\title{
Valuation of Procurement Flexibility in the Machinery and Equipment Industry Using the Real Option Approach
}

\author{
Alexander Kleinert and Volker Stich \\ Forschungsinstitut für Rationalisierung, Pontdriesch 14-16, 52062 Aachen, Germany \\ \{Alexander.Kleinert, Volker.Stich\}@fir.rwth-aachen.de
}

\begin{abstract}
The increasingly uncertain business environment requires the necessity to implement more flexibility in companies. Unfortunately, companies being specialized in engineer-to-order production cannot use safety stocks which are generally used in make-to-stock productions to secure flexibility. Therefore, an alternative approach has to be developed to facilitate procurement flexibility for these companies. In this paper, firstly the current situation of production networks of machine tool and equipment manufacturers will be described. Secondly, the shortcomings of current approaches for intercompany coordination will be discussed. Finally, the real option approach will be examined as a mean to evaluate the benefits of procurement flexibility.
\end{abstract}

Keywords: Delivery reliability, flexibility, procurement, real options.

\section{Introduction}

Besides the general market fluctuations, the impact of the financial and economic crisis illustrated the complexity and volatility which today's European machinery and equipment industry has to deal with [1,2]. In addition to challenges like international competition, increasing customer demand, cost pressure, shortened product life cycles and a rising number of variants, manufacturers have to face increased financial problems and even higher fluctuations in demand $[3,4,5,6]$.

While formerly only programmes for reducing stocks were used to minimize the financial needs, nowadays alternative flexibility potentials, such as the introduction of short-time work, have to be used. [7]. Nevertheless, in increasing non-centralised and temporary production networks, it is not enough to focus only on own resources [8]. With the high amount of outsourcing of complete modules the potential of time and capacity flexibility in the order process has to be used in order to keep the potential sales volume. By using delivery time flexibility within the order process many problems that effect especially modules could be reduced. In particular, the increased delivery time flexibility reduces the negative effects of early or late deliveries that lead to high fluctuations in the whole production network and cause a substantial economic expense [9]. Possible penalties, insufficient ability to plan, high safety stocks, raised lead times and lower service levels are often the result [10]. In a global industry survey, the "suppliers' reliability" was evaluated as the third biggest cause of 
potential risks [11]. However, up to now the expenses which are generated by the insufficient delivery reliability in the machinery and equipment industry cannot be quantified in a satisfactory measure [12].

In order to find solutions for these challenges in procurement, research is conducted. Since September 2009, the Research Institute of Operations Management (FIR) and the Laboratory for Machine Tools and Production Engineering (WZL) at the RWTH Aachen, Germany, analyse in cooperation with ten European partner institutions from industry and research various approaches to improve the interplant communication, transparency and coordination within the research project "InTime in time delivery in non-hierarchical manufacturing networks" (http://www.fp7intime.eu/)

\section{Scientific Approaches on Procurement and Logistics in Production Networks}

The machinery and equipment industry differs by heterogeneous and constantly changing production networks substantially from other industries like the automotive and trading industry (Fig. 1) [13]. On the one hand, intensive relationships exist only for a small share of active suppliers. On the other hand, the production network in the machinery and equipment industry is not as highly dominated by a single company as in the automotive or trading industry.

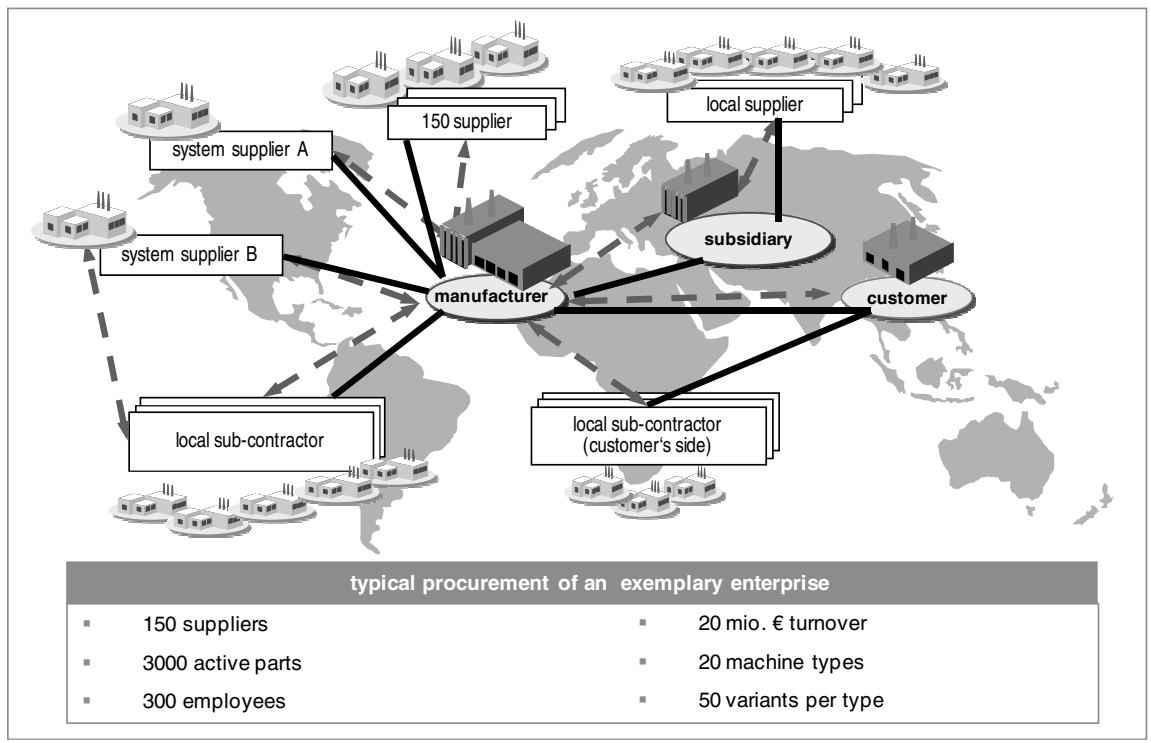

Fig. 1. Non-centralised production network in the machinery and equipment industry

In an industry like this a continuous IT integration can hardly be accomplished by existing data standards such as EDIFACT which is used via sub-standards like Odette in the automotive industry or EANCOM in the trading industry [14]. Hence, many 
proven approaches for streamlining the value chain, which are based on a continuous IT integration without interfaces, cannot be used either [15]. One of these approaches is the "Just in Time" concept (JIT). This production-synchronous delivery on demand pursues the objective to reduce stocks and thereby costs of procurement logistics [16]. Therefore, requirements are careful supplier selection, nearness to supplier, ITsupported integration of the supplier as well as a production targeting mass manufacturing [17]. Besides the missing IT integration, mass production rarely exists in the machinery and equipment industry. Another approach is "Quick Response" (QR) which is based on "process shaping", enabling suppliers to react rapidly on fluctuation in demand $[18,19]$. The start of production is only triggered by short term demand requirements [20]. In machinery and equipment industries short reaction times are rarely in focus, as the make-to-order production requires an extended manufacturing time. Another approach, the Continuous Replenishment (CR) focuses on a high level of shelf availability with low stocks at the same time [19]. Its focus is the automatic delivery of goods as soon as the requirement is set. Regarding the project and order specific requirements, this approach cannot be applied for the machinery and equipment industry either. While the delivery reliability in the automotive or trading industry was increased by these approaches by up to $95 \%$, this rate constitutes only $60 \%$ in the machinery and equipment industry [21].

Nowadays in the machinery and equipment industry, either one uses Andler's formula minimizing the sum of stock and procurement costs or one orders from the supplier who offers the minimal component costs [22]. This static method based on costs and quantities, includes neither uncertainties of the dynamic business environment nor the value of delivery accuracy. Since outsourced components might make up to one fifth of the overall project value, component orders that appear more an investment than a typical order must be treated differently.

Furthermore, the arrangement of divergent target systems of a company becomes continuously an additional challenge for the overall company's performance. While employees in purchasing have usually the incentive to reduce purchase costs, the production department strives for a high degree of utilisation and short lead times and the sales department is urged to generate high turnovers. In addition, differing intercompany target systems exist. Thus, situations often occur in which the customer's purchasing department and the supplier's distribution departments negotiate without considering the consequences for their production departments [23]. This can lead to insufficient capacities on the supplier's site intending to keep the delivery date and to high expenses on customer's site due to earlier or late deliveries. For many years, management science on human resources has been claiming that incentive schemes lead to improved employees' performance. Although such incentives are still not established company-wide, a current study of the FIR and WZL shows that demand in new concepts exists [12]. For the improvement of the situation, consistent and company-wide performance indicators are necessary to calculate incentives. Various performance evaluation systems already exist like the SCOR model or the Balanced Scorecard model. These models offer general performance indicators but do not fit sufficiently enough to the challenge of delivery reliability. Concepts like the "Kennlinienmodell" by Nyhuis and Wiendahl, regard delivery reliability but mainly focus on make-to-stock productions [24]. 
The investigation of relevant approaches for procurement logistics shows that various concepts already exist for company-wide synchronisation, determination of procurement costs and motivation of employees. Nevertheless, these concepts provide few instructions how the procurement in machinery and equipment industry should operate flexible and value-oriented with rising outsourcing of high-quality modules in times of uncertainty.

\section{The Real Option Approach as an Instrument to Increase Flexibility for Uncertain Situations}

The analysis of the present situation showed that an instrument is necessary to assess and control the procurement process of make-to-order components more dynamically and proactively. Due to the high uncertainty in manufacturing processes, a method to increase the flexibility has to be used. One method increasing companies' flexibility that has been used within the last years is the real option approach [25]. So far, this method proved to be a possible approach to evaluate investments and innovative projects (Fig. 2).

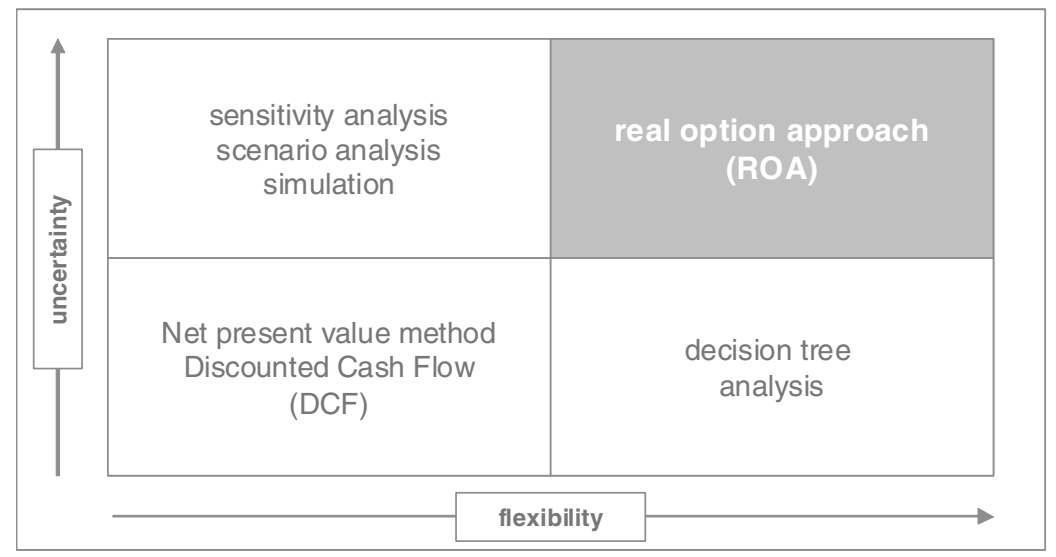

Fig. 2. Valuation methods in regard to flexibility and uncertainty $([26,27])$

After a short introduction to the theory of this approach, it will be illustrated to what extent options can be used in the order process of high-quality components. Furthermore, the required conditions of the approach will be analysed and a possible methodology to calculate the real option for capacity flexibility will be described.

\subsection{Fundamentals of the Real Option Approach}

Originally, the real option approach was developed in the disciplines of financial and decision-making sciences to adapt the assessment of financial options on the 
assessment of investments in "real" assets [28,29]. The basic idea was established by MYERS which states that investment possibilities should be evaluated according to the changes of project-value through possible follow-up investments in the future [30]. Like ordinary financial options, real options offer the right, but not the commitment to accomplish an investment in the future. Therefore, real options create the possibility to adapt investments and its scopes to changing environmental conditions [31]. Hence, the value of a real option increases with an increasing uncertainty about future developments [32]. In case of unpredictable events an essential scope for action can be established using the real option approach [33]. Instead to make an investment decision on a certain date, an option allows to postponing the decision in favour or against the investment (fig. 3).

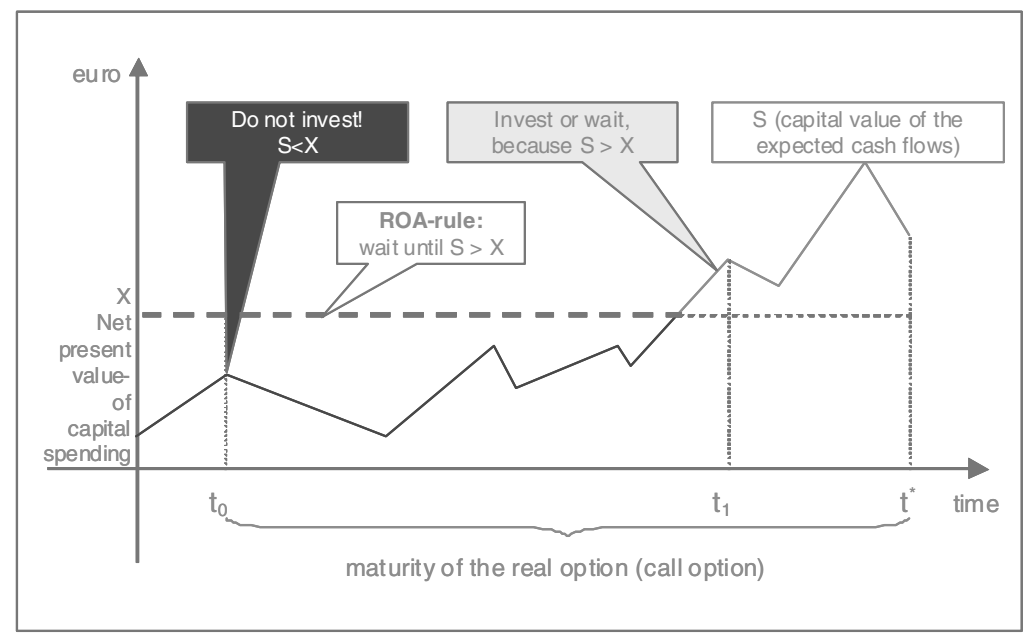

Fig. 3. Scope for decision-making with the real option approach [32]

Since people from industry are usually quite sceptical about the application of the real option approach due to the high mathematical complexity and many restrictions, a methodology has to be developed facilitating the application of the intuitive character of the option approach on the topic of the flexibility of orders. Additionally, it ought to assist the user's comprehension through an adequate level of complexity. Not only is the real option approach meant to be used as an instrument for identification, evaluation and control of options but should also augment the understanding of the decision makers concerning their scope of action [34].

\subsection{Introduction of Options in the Procurement Order Process}

Purchasing processes in the machinery and equipment industry usually have uncertainties and alterations implied, especially when considerable modules are to be manufactured externally. Generally, at the beginning of a contract, a delivery date is 
set with the supplier to which the external service is to be completed. In case that during the production time new requirements are set on the part of the manufacturer or the customer, it would be an advantage if the possibility existed to access additional capacities of the supplier (fig. 4). Such a capacity option is to be considered as a guarantee for the manufacturer when the contract is concluded. The supplier ensures to provide additional capacities in order to maintain the delivery date.

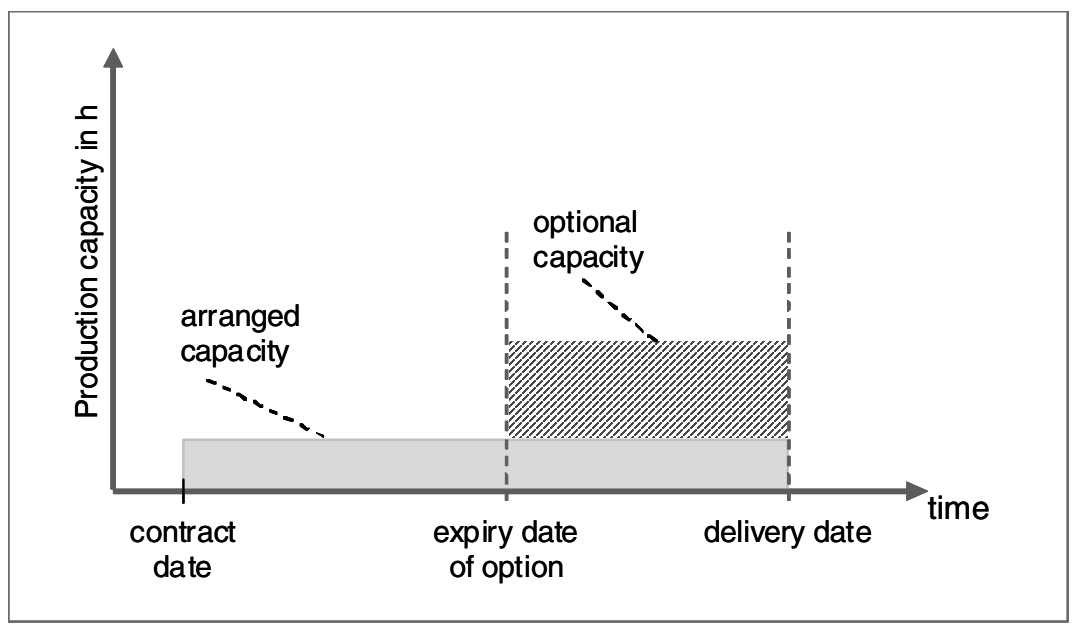

Fig. 4. Option on capacity extension

\subsection{Conditions for the Application of the Real Option Approach on the Assessment of Procurement Order Flexibility}

A precondition for the application of the real option approach on a new problem is the existence of exclusivity, flexibility, uncertainty, irreversibility and an investment (fig. 5) $[29,35]$. The reservation of capacities can be seen as an exclusive or at least advantageous initial situation for the utilization of capacities insofar the contractor the guarantees the reservation. As on reservation of capacities, no obligation but the right exists to access the additional capacities if a requirement on additional flexibility is needed. Uncertainties exist because the benefit of delivery reliability is unpredictable in the setup phase of the contract. The once paid reservation fee is irreversible and must be recorded as "sunk cost". The attribute of an investment can be verified if cash flows exist that begin with outgoing payments and result in incoming payments [36]. The investment in a timely delivery of a module in form of capacity reservation constitutes an investment in an intangible. It starts with a payment to the supplier for the capacity reservation and might result in an additive delivery reliability representing an advantage in terms of reduced setup time, rescheduling or delay costs, as well as possible follow-up orders. 


\begin{tabular}{|c|l|l|}
\hline Attributes & \multicolumn{1}{|c|}{ Financial option } & \multicolumn{1}{c|}{ Option on capacity extension } \\
\hline exclusiveness & $\begin{array}{l}\text { Sole right of the owner to buy (Call) or } \\
\text { sell (Put) a finacial title within a period for } \\
\text { a predetermined price. }\end{array}$ & $\begin{array}{l}\text { Exclusive reservation of production } \\
\text { capacities, which can be used to } \\
\text { guarantee the scheduled delivery date. }\end{array}$ \\
\hline flexibility & $\begin{array}{l}\text { Right but not an obligation to excercise } \\
\text { an option. }\end{array}$ & The reservation must not be exercised \\
\hline uncertainty \& & $\begin{array}{l}\text { Excercise is depending on the ex ante } \\
\text { uncertain performance of the financial } \\
\text { title in the future. The uncertainty } \\
\text { disappears over time. }\end{array}$ & $\begin{array}{l}\text { The value of an scheduled delivery is not } \\
\text { precise predictable at conclusion of the } \\
\text { contract. But many uncertainties disappear } \\
\text { over time. }\end{array}$ \\
\hline $\begin{array}{c}\text { gradual } \\
\text { investement }\end{array}$ & $\begin{array}{l}\text { The excercice price is typically a } \\
\text { multiple of the option price. }\end{array}$ & $\begin{array}{l}\text { The usage of development and } \\
\text { production capacities requires further } \\
\text { investment. }\end{array}$ \\
\hline $\begin{array}{l}\text { The option expires with excercise or } \\
\text { break-up (sunk costs). }\end{array}$ & $\begin{array}{l}\text { An once paid option price has to be } \\
\text { recorded as sunk costs. }\end{array}$ \\
\hline
\end{tabular}

Fig. 5. Analogy between financial options and options on capacity extension for delivery reliability

\subsection{Evaluation of the Option on Delivery Reliability}

As the real option approach bases on various value drivers, these value drivers have to be adapted to the assessment of the specific circumstances (fig. 6) [32]. The monetary value of the expected efficiency gain of reduced setup time, rescheduling and delay costs as well as possible follow-up orders is equivalent to the market price of a financial asset. The exercise price can be interpreted as expenses for the supplier's capacity extension. The volatility can be understood as the uncertainty influencing the market price and exercise price. Beside demand fluctuations, uncertainties come from unspecified processes, uncertain events influencing the progress of internal activities or difficulties within the coordination with other suppliers. The dividend can be seen as loss of cash flow by waiting. In this connection, especially performance related expenses like monitoring costs or increased prices of supplier parts are to be mentioned. Increased prices can be caused by extra demand of competitors, general scarcity of raw materials or inflation. The parameters period and risk free interest rate are related to the parameters of financial options. The time period describes when the option on capacity extension expires. The risk free interest rate is usually gathered from the interest rate for short-term federal bonds. 


\begin{tabular}{|l|c|l|}
\hline Financial option & Parameter & Option on capacity extension \\
\hline market price & S & $\begin{array}{l}\text { value of the scheduled delivery } \\
\text { costs that occur if the delivery time is not accurate }\end{array}$ \\
\hline excercise price & X & $\begin{array}{l}\text { costs of scheduled delivery } \\
\text { costs of extra capacity on supplier site }\end{array}$ \\
\hline $\begin{array}{l}\text { volatility of the } \\
\text { stock price }\end{array}$ & O & $\begin{array}{l}\text { process stability in production } \\
\text { fluctuation in demand and production }\end{array}$ \\
\hline option period & t & $\begin{array}{l}\text { option period } \\
\text { period in which the capacity option is executable }\end{array}$ \\
\hline dividends & D & $\begin{array}{l}\text { running costs for monitoring of the } \\
\text { procurement situation } \\
\text { increase of storage fee of the supplier }\end{array}$ \\
\hline riskless rate & i & \begin{tabular}{l} 
riskless rate \\
\hline
\end{tabular}
\end{tabular}

Fig. 6. Value drivers for the option on capacity extension

Regarding the evaluation of option prices the investigation focuses on proven assessment models that explain the complicated structures and connections in a relatively simple way. As such a procedure, the Lattice method offers the possibility to illustrate the benefit of an extended scope of action with the help of a tree structure analysis (fig. 7) [32]. In the first step, different scenarios are established that start on a negotiation date and show the various outcomes on the delivery date. Depending on the events occurring in this time period, different costs emerge due to the supplier's delay on the date of delivery. The discounting of these negative cash flows to the negotiation date results in the net present value of the delay costs. Secondly, another lattice tree is established taking the capacity extension into account. Assuming that the additional supplier's capacities reduce the probability of a delayed delivery, this Lattice tree leads to a lower net present value of the emerging costs. Finally, the option price is calculated by subtracting the net present values from one another. The result is the option price for the reservation fee that has to be paid by the manufacturer to the supplier in order to receive the right to access the supplier's capacity in case of uncertain events. The manufacturer will only access this option if the time accuracy is worth more than the price of the capacity extension.

This monetary valuation of the option price for capacity extension together with the cause-effect analysis of the main impact factors influencing the delivery reliability are the main focus areas of the project InTime. In order to examine the adaptability of the methodology in practice, the approach will be validated in diverse case studies. 


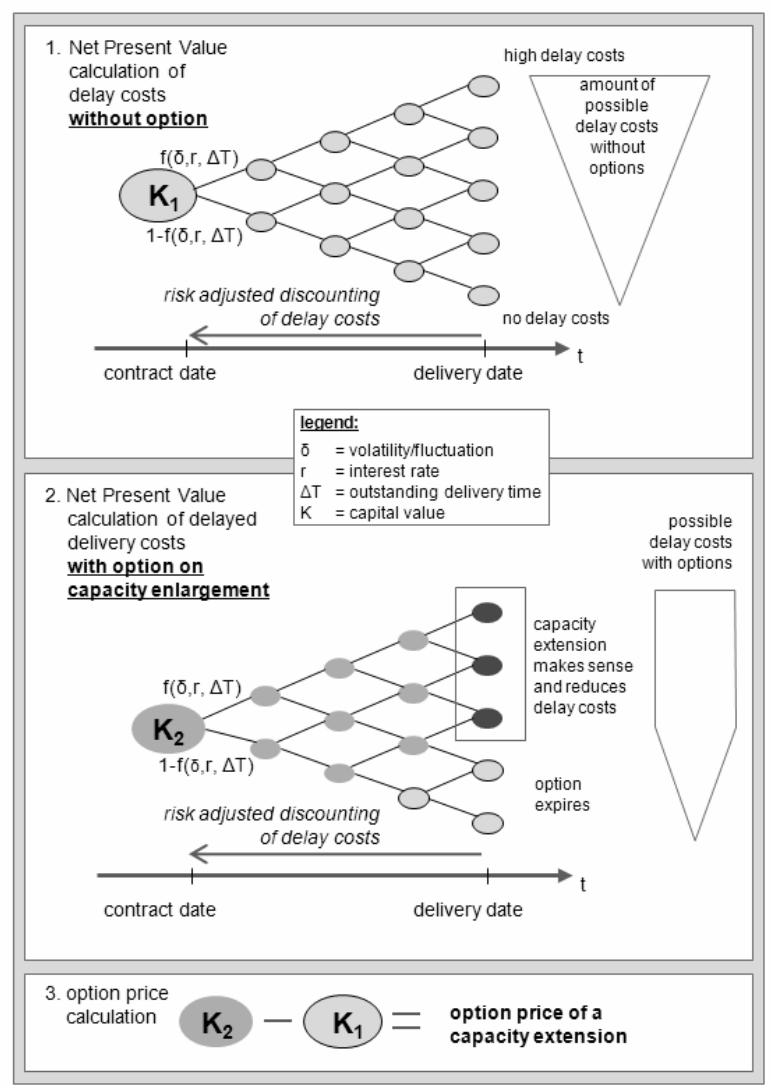

Fig. 7. Evaluation of purchasing flexibility using a lattice tree

\section{Summary and Outlook}

The situation with which producing companies are currently threatened due to the credit and real estate crisis clearly shows that the success of machine and equipment manufacturers does not only result from their technical excellence but also from strict value orientation [37]. Especially the coordination of external manufacturing of components requires new ways of thinking. Innovative methods have to be applied to evaluate, control and optimise logistical objectives like the delivery reliability. Due to its advantage to map the factors uncertainty and flexibility which cannot be represented by conventional evaluation procedures, the real option approach, founded in financial science, gains increasing interest and application within the decision making processes for real assets [33].

The essential advantage of the application of this approach from the point of view of the procurement logistics consists in realising the typical characteristics of deliveries with an option on capacity extension and in showing the effects of value adding. The additional benefit of the flexibility in purchasing can be understood easier by decision makers and, hence, can be included easier in their decision-making. 
Within the framework of the European research project InTime the application of the above mentioned real option approach will be further investigated for the delivery adherence. The objectives are both the determination of the monetary value for timely deliveries as well as an internet-based application facilitating the negotiation of prices between suppliers and customers on such a platform. Finally, the developed models are validated by industrial project partners on the basis of a case study approach.

\section{References}

1. O.V.: Maschinenbau-Aufträge sinken um 42 Prozent, http://www.welt.de/ wirtschaft/article3314855/Maschinenbau-Auftraegesinken-um-42-Prozent.html (02.12.2009)

2. Becker, S.: Deutsche Werkzeugmaschinenindustrie hat Talsohle im Auftragseingang erreicht, http://www.vdma.org/wps /portal/Home/de/Branchen/W/WZM/ Wirtschaft_und_Recht/Int_Maerkte_und_Konjunktur/ Wzm_A_20091105_AE?WCM_GLOBAL_CONTEXT=/vdma/Home/de/ Branchen/W/WZM/Wirtschaft_und_Recht/ Int_Maerkte_und_Konjunktur/Wzm_A_20091105_AE (02.12.2009)

3. Schuh, G., Schweicher, B., Schmidt, C.: Globale Produktion mit flexiblem QuasiStandard. wt Werkstatttechnik online 96(4), 226-232 (2006)

4. Geimer, H., Kühn, H., Salje, R.: Komplexitätsmanagement: Basis für erfolgreiches Supply Chain Management. Supply Chain Management 3, 43-48 (2005)

5. Dierig, C.: Talfahrt im Maschinenbau verlangsamt sich deutlich, http://www.welt.de/die-welt/wirtschaft/article5024420/ Talfahrt-im-Maschinenbau-verlangsamt-sich-deutlich.html (02.12.2009)

6. Knoll, A.: Finanzkrise kommt im Maschinenbau an, http: / / www.elektroniknet.de/home/automation/news / $\mathrm{n} / \mathrm{d} / \mathrm{f}$ inanzkrise-kommt-im-maschinenbau-an/ (02.12.2009)

7. Crimmann, A., Wießner, F.: Verschnaufpause dank Kurzarbeit. Bertelsmann Verlag, Nürnberg (2009)

8. Schmidt, C., Schweicher, B., Walber, B., Wienhold, H.: Referenzmodell überbetrieblicher Koordinationsprozesse: Effiziente Auftragsabwicklung mit myOpenFactory, pp. 73-88. Carl Hanser Verlag, Wien (2008)

9. Grasedyck, O.: Liefertermintreue als Schlüssel zu mehr Wettbewerbsfähigkeit, http: / /www.dieeinkaufsexperten.de/content/e7494/e7579/e8836/ publication8839/LogistikfrUnternehmen5-6-2008LiefertermintreuealsSchlssel zumehrWettbewerbsfhigkeit_ger.pd f (03.02.2010)

10. VDMA: Maschinenbau in Zahl und Bild (2008), http: / /www.ixpos.de/nn_1183434/DE/07Publikationen/00_Downlo ads/VDMA_Maschinenbau2008, templateId=raw, property=publicati onFile.pdf/VDMA_Maschinenbau2008.pdf (03.02.2010)

11. McKinsey Quarterly: Understanding Supply chain Risk. No. 09, pp. 1--9 (2006)

12. Schuh, G., Kampker, A., Narr, C., Jasinski, T., Sander, S., Vogel, C.: Beschaffungslogistik im Maschinen- und Anlagenbau. Apprimus Verlag, Aachen (2009)

13. Stich, V., Kleinert, A., Brosze, T.: A networked business model improving interorganizational processes. In: Helsinki University of Technology (ed.): APMS 2008 Innovations in Networks, pp. 331-335 (2008) 
14. Schuh, G.: MyOpenFactory: In: International Journal of Computer Integrated Manufacturing 21(2), 215 (2006)

15. Pochard, S.: Managing Risks of Supply-Chain Disruptions. Massachusetts Institute of Technology Verlag, Boston (2003)

16. Fandel, G., Francois, P.: Just-in-Time-Produktion und -Beschaffung: ZfB - Zeitschrift für Betriebswirtschaft, pp. 531-544 (1989)

17. Zibell, R.: Just-in-time: Philosophie. Huss Verlag, München (1990)

18. Stölzle, W.: Industrial relationships. Oldenbourg Verlag, Wien (1999)

19. Corsten, D., Gabriel, C.: Supply-Chain-Management erfolgreich umsetzen, 2nd edn. Springer, Tokio (2004)

20. Brehm, L., Ferencak, R.: Potenziale von SCM-Software für das Management unternehmensübergreifender Prozesse, http: / /www. wiso.boku.ac . at/

uploads/media/scm-software2_01.pdf (03.02.2010)

21. Fuchs, S.: Der Weg aus dem Rückstand über Synchronisierung der PPS. Industrieanzeiger 8, $70(2008)$

22. Vahrenkamp, R.: Produktionsmanagement, 6th edn. Oldenbourg Verlag, München (2008)

23. Keller, M., Hellingrath, B.: Kennzahlenbasierte Wirtschaftlichkeitsbewertung in Produktionsund Logistiknetzwerken. In: Otto, A., Obermaier, R. (eds.) Logisitkmanagement, pp. 51-75. Deutscher Universitätsverlag, Wiesbaden (2007)

24. Otto, A., Obermaier, R.: Logistikmanagement, 1st edn. Dt. Univ.-Verlag, Wiesbaden (2007)

25. Lander, D., Pinches, G.: Challenges to the practical implementation of modelling and valuing real options. The Quarterly Review of Economics and Finance 38(Special issue), 537-567 (1998)

26. Hommel, U., Lehmann, H.: Die Bewertung von Investitionsobjekten mit dem Realoptionsansatz. In: Hommel, U., Scholich, M., Vollrath, R. (eds.) Realoptionen in der Unternehmenspraxis, pp. 113-129. Springer, Heidelberg (2001)

27. Copeland, T., Keenan, P.: How much is Flexibility worth? The McKinsey Quarterly 2, 3849 (1998)

28. Trigerorgis, L.: Real Options and Interactions with Financial Flexibility. Financial Management 22(3), 202-224 (1993)

29. Pritsch, G.: Realoptionen als Controlling-Instrument, 1st edn. Dt. Univ.-Verlag, Wiesbaden (2000)

30. Myers, S.: Determinants of corporate Borrowing. Journal of Financial Economics 5(2), 147-176 (1977)

31. Hommel, U., Pritsch, G.: Marktorientierte Investitionsbewertung mit dem Realoptionsansatz. Finanzmarkt und Portfolio Management 13(2), 121-144 (1999)

32. Trigeorgis, L.: Real Options. MIT Press, Cambridge (1996)

33. Batran, A.: Realoptionen in der Lieferantenentwicklung, 1st edn. Betriebswirtschaftlicher Verlag Dr. Th. Gabler, Wiesbaden (2008)

34. Pritsch, G., Weber, J.: Die Bedeutung des Realoptionsansatzes aus Controlling-Sicht. In: Hommel, U., Scholich, M., Vollrath, R. (eds.) Realoptionen in der Unternehmenspraxis, pp. 13-43. Springer, Berlin (2001)

35. Hommel, U., Pritsch, G.: Investitionsbewertung und Unternehmensführung mit dem Realoptionsansatz. In: Achleitner, A., Thoma, G. (eds.) Handbuch Corporate Finance, pp. 1-67. Deutscher Wirtschaftsdienst Verlag, Köln (1999)

36. Götze, U.: Investitionsrechnung, 6th edn. Springer, Berlin (2008)

37. Schuh, G.: Lean Innovation Capability. In: Schuh, G., Wiegand, B. (eds.) Tagungsband/ 5. Aachener Management Tage, pp. 1-18. Apprimus-Verlag, Aachen (2008) 